DOI: $10.17516 / 1997-1370-0227$

УДК 81 '246.3, 81'25

\title{
Conceptual Content of Bi- and Polylingual's Everyday Mind in the Framework of Translation
}

\author{
Polina P. Dashinimaeva, Larisa M. Orbodoeva \\ and Vera B. Sambueva* \\ Buryat State University \\ Ulan-Ude, Russian Federation
}

Received 20.11.2018, received in revised form 24.04.2019, accepted 08.05.2019

\begin{abstract}
The project discovers a way one might explicate a conceptual content of everyday mind to finally reveal difference in modes of cognizing and thinking in the two cultures involved in translation. The methods applied in the study are an association experiment on the basis of most frequent words, conceptualization mode, and incorporating the data into a segmented translation act. The viability of the pilot project is supported by 18 basic frequent lexemes as stimuli to be further given associations in Buryat and Russian, and the processed data to expose versions of conceptual worldview. The paper shows that 80 bi- and polylingual students, who take part in the experiment, could be prototyped as the source and target culture bearers - the ones that contact in intercultural communication through the translator's mediation. The final idea is to introduce and reinforce the importance of modeling translating process in the framework of new methodologies which show that not mere words but concepts are to be translated in communication.
\end{abstract}

Keywords: everyday mind, translation, experiment, associate, image, concept, worldview.

The research is financially supported by Buryat State University, grant no. 44-OD, dated 02 February, 2017.

Research area: language studies.

Citation: Dashinimaeva, P.P., Orbodoeva, L.M., Sambueva, V.B. (2020). Conceptual content of bi- and polylingual's everyday mind in the framework of translation. J. Sib. Fed. Univ. Humanit. Soc. Sci., 13(3), 341-351. DOI: 10.17516/1997-1370-0227.

(C) Siberian Federal University. All rights reserved

* Corresponding author E-mail address: pdash@bsu.ru 


\section{Introduction}

For cross-cultural communication professionals working in the translation mediation domain to determine the worldview held by source culture bearers, which modern linguistics traditionally calls "the conceptual view of the world", seems to be the main challenge. This issue acquires special relevance due to the fact that today a linguistics theorist does realize the deficiency of the horizontal translation model, which is based on learning the "2D" flat-line algorithm with one point (a word or a structure) associated with another one (a word or a structure):

*the source word $\longrightarrow \longrightarrow$ *target equivalent (submit $\longrightarrow$ представлять на рассмотрение);

*source structure $\longrightarrow \longrightarrow$ *target structure (The conference expects to host up to 2,000 educators $\longrightarrow \longrightarrow$ Mы планируем разместить до 2000 участников конференции).

As a rule, traditional approaches to translation modeling explicate only one or two stages in the translator's verbal thinking activity: Linguistic Theory describes the final product of translation as a linguistic sign produced by the translator, while Functional Communication Theory mainly focuses on the initial stage, or the stage of identifying the connection between the meaning and function in the source text. The main problem of such an "intra-linguistic" approach is that it creates an illusion of identity between the worldviews, i. e. universal references existing in the cognitive space of each culture's bearers ("everything is the same everywhere"). However, an individual's social experiences, as well as emotional and moral settings, determine the major knowledge categorization vector, which, in the end, fails to provide universal processing or interiorization. This mechanism proves the validity of Leibniz's "salva veritate" postulate, which states that the truths of the mind do not always correspond to the truths of the outside world, and that "everything is different everywhere", thus emphasizing the differences in cognizing and thinking.

\section{Substantiation of the methodology \\ for studying the everyday mind \\ of culture bearers in translation}

A deeper understanding of the intercultural communication mediation notion facilitates the necessity to implement the vertical principle and create a "3D" algorithm. This approach is reasonably called monadic / atomic, because it, firstly, brings us to the actual process of verbal thinking, i. e. to the addresser and the addressee's "black box" stage, which further prompts an attempt to explicate "what is thought behind the word"; secondly, to a certain extent it employs the idealization method in solving a research problem - a method that may lead the researcher away from implementing the reliability principle. In accordance with the salva veritate principle, it is important to reveal the differences in associative thinking in the two contacting cultures. It may become possible if we synthesize the data obtained from a frequency dictionary and an associative experiment.

It is worth noting that a frequency word list provides useful information for understanding a culture: the more frequent this or that lexeme in different text types is, the more expressively it indicates towards identification of cultural zones. However, the associative content of these zones remains unknown, which prompts an associative experiment with the most frequent - nuclear - lexemes serving as stimuli. We implemented a project of this kind within the framework of the grant project "Language determination of the everyday mind content in bi- and polylingual individuals" (Buryat State University, 2017). Such a project is of extra interest in a region like the Republic of Buryatia, where one can find bearers of different languages and cultures, for the following reasons: 1. It generally defines the basic conceptual guidelines of the source culture, whose bearer is involved in cross-language communication; 2 . The subjects present a mini-sample of an intercultural space.

It should also be noted that frequency of the signs is an indicator or factor "exploited" for various research objectives. For example, Gideon Toury, a theorist from the University of Tel Aviv, employs the idea of frequency in his 
probabilistic, conditioned translation concept to prove the lack of ready-made, universal correspondences. Thus, the principle of frequency as the basis of his theory says: the lower the frequency, the less universal is the use of a unit, and, conversely, the more obviously probabilistic and prognostic is the use of a corresponding unit. Toury argues that we cannot state that the correlating word use has a determined character due to the involvement of several mutually opposing factors: cognitive, cross-linguistic, communicative, socio-cultural; and all these factors cause heterogeneity of relations (Toury, 2004). In this case, frequency is understood at two levels - on the one hand, a "specificsynchronic" slicing of occurrence, and, on the other hand, a diachronic-generalized result, which makes a conclusion about frequency in the presence of a corpus database (Toury, 2004: 19). Toury's concept brings us to an idea that the most important problem for translation theory is instrumentalization, or operationalization, of the translation methodology, so as to minimize the search for relevant correlates.

To develop a valid methodology for determining conceptual semantics, one must choose the most relevant genre for further research. The author's conceptual worldview reflecting the everyday mind, is objectified most obviously in such genres as public speech, publicist text, newspaper and magazine information text. In this regard, in our study we turned to the publicist style.

\section{Methods of the experiment}

The research project algorithm consisted of the following research procedures:

1. Identification of two subject categories - bilingual, and polylingual ones who study foreign languages, including translation.

2. Selection of a frequency word list for Russian and Buryat languages based on publicist texts.

3. A free associative experiment.

4. Processing of the experimental data: descending order distribution of the received reactions according to their frequency, determination of associative fields.

5. Comparison of the associative meanings of Buryat and Russian common correlates from the frequency word list, identification of the general and differential conceptual space.

6. Definition (in the first approximation) of the characteristics pointing to the Buryat conceptual way of thinking in the respondents who identified themselves as Buryats, but presented associations in the Russian language.

7. Identification of fragments of the Buryat and Russian conceptual worldview on the basis of frequency reactions.

8. Recommendations on translating Buryat and Russian texts that contain frequent words, taking into account their associative semantics.

A free association experiment was conducted from April to May 2017. For further portraiture the subjects were given a questionnaire in the Russian and Buryat languages. The respondents were asked to provide the following personal information: name, age, sex, education/course of study, place of the longest residence (city/village), mother tongue, other languages spoken by the subject. Next, they were presented with the following task: "Read this word and write the first reaction to it that comes to your mind".

The experiment reached 40 bilingual subjects who speak Russian as a native language and a foreign language, and 40 polylingual subjects who speak Buryat as their mother tongue, Russian and a foreign language. The respondents were aged from 17 to 25 , the geographical locale of the experiment - the Republic of Buryatia and Zabaikalsky Krai (Russia).

According to the results of the experiment, 40 Buryat-speaking respondents were divided into 3 groups:

1) 28 subjects who responded to Buryat stimuli in the Buryat language;

2) 2 subjects who responded to Buryat stimuli in the Russian language;

3) 10 subjects who chose stimuli in the Russian language, and, accordingly, responded in Russian, too.

This ratio is quite indicative, as it confirms the functional regression of the Buryat language, which has been described by linguists in Buryatia (Dyrkheeva, 2017; Zhalsanova, 2017). Our experiment shows that the 
status of the Buryat language in 12 respondents $(30 \%)$ cannot be defined as the first/ native language, and that their bilingualism has changed its format from Buryat-Russian to Russian-Buryat, although in the questionnaires these subjects mentioned Buryat as their native language. Such a factor as a quick response to a stimulus through the use of the Russian language code illustrates their cognitive inability to unconscious response activation in the Buryat language. This means that the corresponding neural connections responsible for objectifying the equivalents in the Russian language win the inter-language production competition.

The obtained data were processed in quantitative and qualitative aspects. As a result, all reactions formed an associative verbal network relevant for 2017. lowing:

It is essential to pay attention to the fol-

1. Single reactions representing a unique way of the external world interiorization allow us to speak about the stochastic (indefiniteprobabilistic) nature of mental images and personal significances. Therefore, they cannot be included in the worldview images hierarchy.

2. The conceptual content of the culture bearer's everyday mind is indicated not by the language code (language body), but by the associative content behind this body.

3. We determine the status of primary Buryat / primary Russian conceptual mind through the content, rather than the language code in which the response is given.

\section{The course of the experiment \\ and the primary processing \\ of the material obtained}

For the experiment we chose a word list based on The Buryad Unen newspaper's thesaurus compiled by P. Dashinimaeva from the materials that included all of this newspaper's issues for the years 2007 and 2008 (The Buryad Unen is the only regular newspaper published in the Republic of Buryatia in the Buryat language) (Dashinimaeva, 2017).

Personal and possessive pronouns, numerals and verbs have been removed from the list of 100 Buryat words representing significant words. Thus, the first 18 words were included in the list of would-be stimuli: azhal (work), zhael (year), olon (a lot), arad/zon (nation/people), hun (man), sug (time), ger (house), aimag (village), gazar (land/home), hain/haehan (good/beautiful), burkhan (god/altar), naerae (name), huuli (law), bagshah (teacher), khaan (the king/owner), udaer (day), shenae (new), uran (skilled, clever), sagaan (white).

To select stimuli words in Russian, we turned to the "New frequency dictionary of Russian vocabulary" (Available at: http://dict.ruslang.ru/freq.php (date accessed 02.03.2017)). This dictionary, in our opinion, is the most reliable and modern one, as it is based on the collection of texts from the National Corpus of the Russian language (the texts were produced in the period 1950-2007). The greatest advantage of this frequency dictionary is the distribution of lemmas by functional styles. In the dictionary the lemmas are arranged in alphabetical order and have one "total frequency" statistical indicator. Taking this indicator as the key one we selected words-stimuli - independent parts of speech previously removing the same word categories as for the Buryat word list. As a result, we obtained the following list of 18 words-stimuli: god (year), chelovek (man), vse (all), odin (one), vremya (time), drugoi (another), perviy (first), noviy (new), zhizn' (life), delo (deed/business), dva (two), den' (day), strana (country), slovo (word), dom (home), drug (friend), mir (world), posledniy (last).

The results of the experiment show that the responses to the stimuli directly and indirectly indicate how an individual's everyday thinking occurs. After all, we do not think through interpretations of an object's physical properties and characteristics, which we can find in dictionaries, but through figurative associations of an object's copies that have been formed during one's life in the process of socialization. In order to get a clearer understanding of the inner worldview's content, we must define the type of the image-category, which will form the basis for further classification. These include living being images, quality images, abstraction images, reference images, institution images, and action images. 
Thus, significant for the linguistic mind of a younger generation of Buryat polylingual speakers are:

- living being images: zon (people) (18), hun (human) (13), basagan (girl, daughter) (10), Genghis Khan (8), aezhi (mother) (7), arad (people) (7), erae hun (man) (7), uhiboon (child) (5), bagshah (teacher) (5), Dalai Lama (3), khuboon (boy, young man, son) (2);

- quality images: tomo (big) (8), muu/ moukhai (bad) (6), saeber (clean) (5), yekhe (much, many) (5), nogoon (green) (5), goyo (beautiful, smart) (4), hain (good, well) (4), khara (black) (4), uner (smell) (3), shene (new) (3);

- abstraction images: buryad (Buryat,) (10), delkhay (world, light, earth) (7), zhel (year) (7), uder (day) (7), sedhel (thought) (6), obog (surname) (6), hanaan (thought, desire, intention) (4), erdem (knowledge, science, education) (4), ubel (winter) (4);

- reference images: mungen (money) (10), naran (sun) (10), ger (house) (9), edean (food, (8), nom (book) (7), zula (candle, oil lamp) (4), gazar (land) (3), seseg (flower) (3), khubsahan (clothes, dress) (2), khargy (road) (2), altan (gold) (2);

- institution images: hurguuli (school) (12), ger bule (family) (7), dasan (datsan - Buddhist temple) (6), zasag (power) (6), hudalmeri/ azhal (work, labour) (6);

- action images: mendeshelkhe (to greet) (2), zokhyokho (to create) (2), sai urgekhe (to make offering with tea) (2).

It is interesting to compare the associative fields of the two respondents who gave their responses to Buryat stimuli in Russian. The first respondent found it difficult to suggest associations for the following words: olon (a lot), hun (human), haehan (beautiful), burkhan (God/ altar), huuli (law), uran (skillful), the last four of which do not belong to the basic vocabulary, although in the publicist text they do, as such texts cover social issues. This inability to identify these Buryat stimuli at the individual level confirms the statement made by B. Bichakjian, who argues that language regression is a gradual "departure" to the previous positions (the basic vocabulary): sign A is regularly replaced by sign $\mathrm{B}$, and the latter is recognized as having a selective advantage (Bichakjian, 1999). This means that in the process of permanent selection Russian equivalents have already replaced less regular units from the bearer's memory and reduced the lexicon to its basic state.

The second subject did not have a reversive stage in the native language functioning: she managed to understand all Buryat stimuli correctly, which means that her language proficiency is at the border point: further weakening of the language functioning will trigger reverse movement to the previous positions. However, the responses given by these two respondents in Russian drive us to a conclusion that their everyday mind still holds the Buryat conceptual worldview (e. g. aimag (native village) vs rodina (homeland), zon (folks/tribe) vs rodniye (kin), burkhan (god) vs umirotvoreniye (tranquility), nerae (name) vs ya (I), sagaan (white) vs sebaer (pure). The rest of the responses were characterized by a high degree of denotation - the meaning that weakly points to the conceptual-evaluative mind content.

Now we shall consider if the last conclusion could be attributed to the 10 Buryat polylingual respondents who chose both stimuli and responses in Russian. Of the whole group, the verbal behavior of 3 respondents proved to be the most obviously ethnically-oriented, as they presented their everyday mind in a slightly different way, thus expressing Buryat identity in an obvious manner. Analysis of such responses as one vs tree, time vs eternity, another vs new, life vs nature, country vs map, state, year vs age, person vs head, time vs life, another one vs different, new, friend - zero reaction suggests that their minds hold a certain world model formed by the generations of ancestors who had a nomadic lifestyle. As A.T. Zhanaev aptly notes, "the Oriental [Buryat] way of thinking is characterized by relativity and holistic thinking, which implies integrity of the part and the whole, non-dichotomous categorization, high context of statements, vision of the world as a dynamic whole" (Zhanaev, 2014: 6-7).

Thus, out of 40 subjects who identified Buryat as their native language, we could identify 33 respondents, whose everyday mind can be described as "Buryat-oriented". 
Further, we shall present 6 imagecategories, which are reflected in the associations of 40 Russian-speaking bilingual respondents:

- abstraction images: mir (peace) (15), noch' (night) (15), Rossiya (Russia) (14), den' (day) (13), dva (two) (12), god (year) (11), yazyk (language) (9), zhizn' (life) (8), smert' (death) (7), rodina (homeland) (7), lubov' (love) (7), para (couple) (7), tri (three) (7), rozhediye (birth) (6), voina (war) (5), gorod (city) (5), mesto (place) (5), chislo (number) (5), mesyatz (month) (4), utro (morning) (4), shchastye (happiness) (3), radost' (joy) (3), planeta (planet) (3), vselennaya (universe) (2), vechnost' (eternity) (2);

- quality images: luchshiy (best) (10), chuzhoi (alien) (7), mnogo (many) (6), horoshiy (good) (6), stariy (old) (5), svetliy (light) (4), geroi (hero) (4), vrag (enemy) (4), rodnoy (native) (3), vazhnoye (important) (3), posledny (last) (3), perviy (first) (3), nepohozhiy (unlike)
(3), inoi (other) (3), bystro (fast) (3), lider (leader) (2), chistiy (clean) (2), dobroye (kind) (2);

- living being images: chelovek (human) (18), l'udy (people) (11), drug (friend) (9), lichnost' (personality (6), ya (I) (5), muzhchina (man) (4), mama (mother) (3), roditeli (parents) (3), sushestvo (creature) (3);

- institution images: semya (family) (19), rabota (work) (7), biznes (business) (4), obshestvo (society) (2), uchyoba (studies) (2);

- reference images: solntze (sun) (11), chasy (clock) (11), dom (house) (7), zemlya (earth) (5), telefon (telephone) (3), ochag (hearth) (3);

- action images: idyot (goes) (2).

In addition to the above mentioned denotative-referential meanings of the associates there are also syntagmatic combinations that are not quite presentable for correlation with the conceptual worldview: predicative logogens, which are forms of a communication strategy sai urgekhe (to make offerings

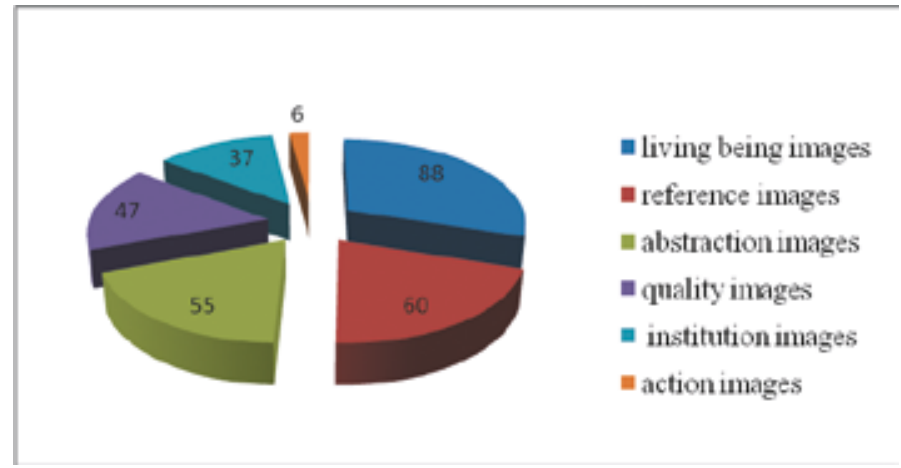

Fig. 1. The ratio of everyday mind images of 28 Buryat-speaking respondents

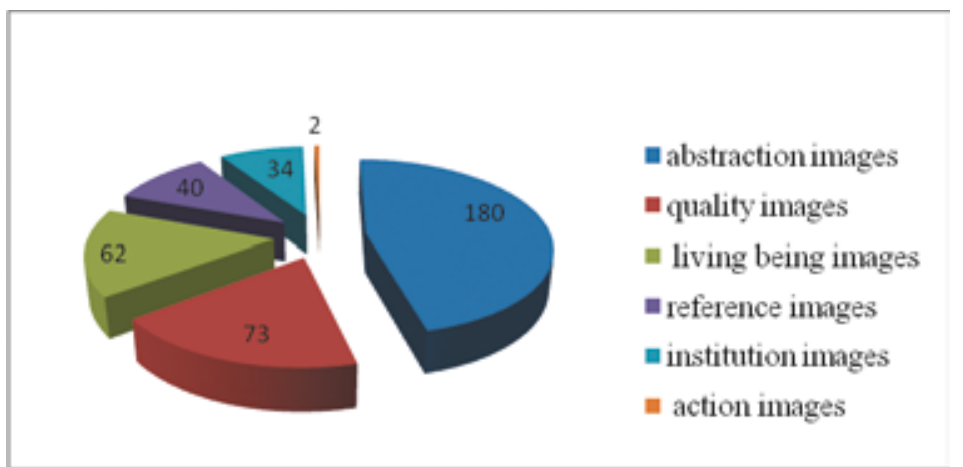

Fig. 2. The ratio of everyday mind images of 40 Russian-speaking respondents 
with tea), vremya idyot (time passes), etc., semi-predicative combinations like gaerei dabari (homework), Baeshuur aimag (Bichura village), etc. Such reactions demonstrate in practice production and perception regularity of the combinations, which provides their easy unconscious activation prior to detecting their inherent paradigmatic connections and relationships.

The ratio of associative images behind the stimulus words in Buryat and Russian is presented in Fig. 1 and 2.

\section{Determination of primary Buryat and primary Russian \\ everyday mind conceptual content}

Further, on the basis of correlation and convergence of the images according to the semantic kinship principle and verbal reactions frequency, we define the concepts that we understand as acts of consciousness determining the intention and the course of the thinking process; the associates that received 3 or fewer responses were excluded from conceptually significant space determinants. The concepts defined on the basis of the experiment only, which involved 80 participants of approximately the same age and one field of study, form only the primary Buryat or primary Russian conceptual worldview: a number of complementary experiments are necessary in order to obtain a closer approximation.

The primary Buryat conceptual content, allocated on the basis of 28 fields, consists of the following concepts (we do not include here the bi-coded reactions of 12 Buryat-speaking subjects that have been given certain assessment in the previous paragraph):

1. The WE - ETHNOS concept represented by the responses: zon, arad (people, nation) (18), hun (human) (13), buryad (Buryat) (10), Genghis Khan (8) (which points to the roots of the ethnic group going back to the era of Genghis Khan).

2. The I - FAMILY concept represented by the responses: ger (house) (9), ger-bulae (family) (7), ezhy (mother) (7), basagan (girl, daughter) (10), erae hun (man) (7), obog (last name) (6), ukhiboon (child) (4).
3. The I - UNIVERSE concept represented by the responses naran (sun) (10), delkhey (peace, light, earth) (7), zhel (year) (7), uder (day) (7), nogon (grass, green) (5), ubel (winter) (4).

4. The I-MATERIAL WORLD concept represented by responses mungen (money) (10), edaen (food) (8), tomo (big) (8), muu/muuhai (bad) (6), ekhae (a lot, big) (5), goyo (beautiful, smart) (4), khara (black) (4).

5. The I-SOCIETY concept represented by the responses of hurguuli (school) (12), dasan (datsan - Buddhist temple) (6), zasag (power) (6), khudelmeri/azhal (work, labour) (6), bagsha (teacher) (5).

6. The I-SPIRITUAL WORLD concept represented by the responses: nom (book) (7), sad'hel (thought) (6), sebaer (pure) (5), erdem (knowledge) (4), hanaan (thought, desire, intention) (4), zula (candle, oil lamp) (4), hain (good, well) (4).

The primary-Russian everyday mind conceptual content selected on the basis of 40 associative fields (as above, responses from 3 to 0 were excluded as conceptual determinants):

1. The I - UNIVERSE concept represented by the responses: mir (world) (15), noch' (night) (15), den' (day) (13), god (year) (11), solntse (sun) (11), mesyatz (month) (4), utro (morning) (4).

2. The I-SOCIETY concept represented by the responses: drug (friend) (9), zhizn' (life) (8), smert' (death) (7), chuzoi (alien) (7), rabota (work) (7), lichnost (personality) (6), voina (war) (5), gorod (city) (5), ya (I) (5), mesto (place) (5), biznes (business) (4), muzhchina (man) (4).

3. The WE - ETHNOS concept represented by the responses: chelovek (human) (18), Rossiya (Russia) (14), l'udi (people) (11), rodina (homeland) (7), zemlya (earth) (5), geroi (hero) (4), vrag (enemy) (4).

4. The I - MATERIAL WORLD concept represented by the responses: dva (two) (12), chasy (clock) (11), luchshiy (best) (10), para (pair) (7), tri (three) (7), mnogo (many) (6), chislo (number) (5), stariy (old) (5).

5. The I - FAMILY concept represented by the associates: semya (family) (19), dom (house) (7), rozhdeniye (birth) (6). 


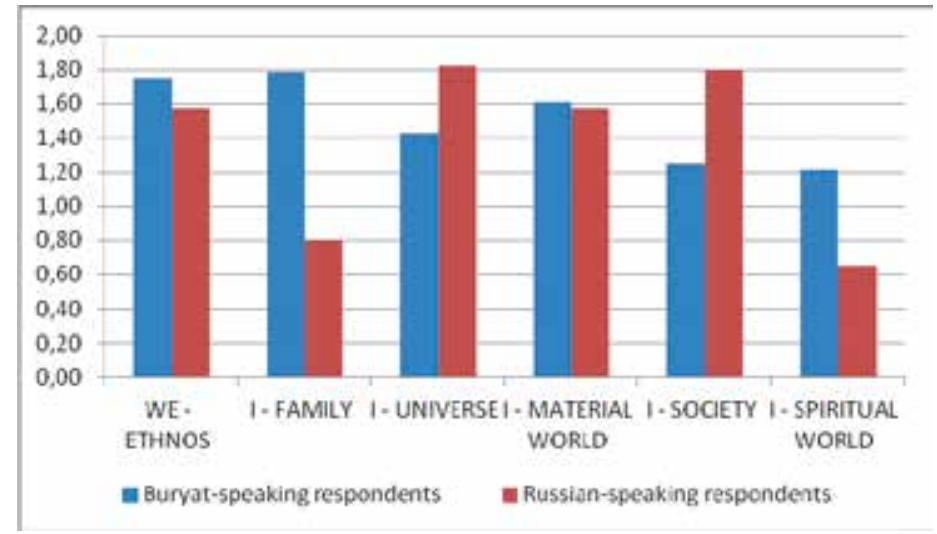

Fig. 3. Ratio of the everyday mind content in the two categories of respondents

6. The I-SPIRITUAL WORLD concept represented by the responses: yazyk (language) (9), l'ubov (love) (7), khoroshiy (good) (6), svetliy (light) (4).

Thus, from the associative fields formed on the basis of responses to 18 frequency stimuli, we could distinguish 6 general concepts, which nevertheless differ in their internal content. In the lists the hierarchy of concepts was built according to the frequency of language presentations. However, to obtain a relevant theoretical generalization, it is necessary to neutralize the asymmetry of the fields ( 28 and 40 ), i. e. to compare the conceptual content of the everyday mind in the two respondent categories on the basis of the given value - the coefficient relative to the participants share. As a result, we obtained the following ratio (see Fig. 3).

As one can see, the situation with Buryatspeaking participants is represented more by the I-FAMILY and WE - ETHNOS concepts, while in the case of Russian-speaking respondents the I - UNIVERSE and I - SOCIETY concepts dominated, which, in general, appears to be quite predictable.

\section{Determination of the conceptual worldview of the source culture bearers as a starting point in pre-translation work}

Within the framework of the cognitivepsychological approach, translation is considered not as a search for the most suitable correlates, but rather as the translator's ability to predict the meaning of the source text on the basis of understanding the stereotyped conceptual worldview, which we have tried to present. However, a translator meets a certain languageculture bearer rather than a generalized culture representative, thus, it is extremely important for the translator to employ his/her ability to relativize the stereotypical knowledge of the nation's conceptual orientations through identification of the addressee's psycho-typical, social and personal characteristics. As a result, the translator identifies the author as a typical / average / peripheral representative of this culture. In order to be able to do this, the translator must undergo a certain evolution, which involves a qualitative increase in the ability to determine translation units within the following proportion rule: the lower is the translator's level of professional competence, the more formal-linguistic a translation unit is, and vice versa, the higher the translator's skill level, the more mental (internal) structure this unit becomes (Dashinimaeva, 2017):

- pre-professional level: formal translation unit (morpheme, word, syntagm, sentence);

- better developed translation skills: translation units as meanings of the source text, which are conditioned by its function;

- almost perfect translation skills: translation units as "internal" units - cognitive structures (primarily conceptual reference-points).

Moreover, this is not only about the ability to determine a concept as a translation unit, but also about the ability to model the translation 
process as a semiotic mechanism consisting of mental, pre-verbal-pragmatic and verbal stages. In the didactic aspect, the first stage implies the need to develop the ability to predict and imagine the addressee's mental structures, and then, already being a shadow sender, to "try on" the addressee's everyday mind.

Let us illustrate this idea with an example of what might result from insufficient conceptual knowledge of the source culture and a neglected pre-translation stage: we will refer to a translation of Bair Dugarov's poem The Nomad's Star (1994). The translation was made by Laurie Daniels, an American poet, in 1996: resentative of his culture, which is proved by his poetry in general), so the sky cannot be part of a grass blade.

This example shows that mere knowledge of the target language is not enough: it is necessary to realize what concepts underlie the text. When it is necessary to reproduce in another language a Buryat text of this kind, where ethno-oriented content is significant, the translator needs, first of all, to find out about the associative content of the I - FAMILY and WE - ETHNOS, I UNIVERSE and I - MATERIAL WORLD concepts, etc., then compare the representa-

\begin{tabular}{|l|l|}
\hline \multicolumn{1}{|c|}{ ЗВЕЗДА КОЧЕВНИКА } & \multicolumn{1}{c|}{ THE NOMAD’S STAR } \\
\hline Мужчине - путь, а женщине - очаг. & The road is to man, as the hearth is to woman. \\
И чтобы род мой древний не зачах, & And so my ancient clan does not wither, \\
роди - молю и заклинаю - сына. & A son is born - I pray and entreat. \\
Стрела летит, покуда жив мужчина. & The arrow flies, as long as man is alive. \\
Мужчине - дым, а женщие - огонь. & Smoke is to man, as fire is to woman. \\
И чтоб в бою мой не споткнулся конь, & And so my steed does not stumble in battle \\
я должен знать, что юрту греет пламя, & I must know that a flame warms the yurta, \\
как предками завещанное знамя. & Like the banner hung by my forefathers. \\
В мужчине - дух, а в женщине - душа. & In the man lies the spirit, in the woman, the soul. \\
Травинка держит небо трепеща. & The trembling blade of grass contains the sky. \\
Без очага, без сына, без любимой, & Without a hearth, without a son, without my beloved, \\
как одинокий смерч, развеюсь над равниной. & I am scattered above the plain, \\
& like a solitary sandstorm. \\
\hline
\end{tabular}

It is easy to see that this is a word-forword linear translation (translation units are words and grammatical structures). The translator fails to detect, for example, what stands behind such concept words as (BURYAT) MAN, (BURYAT) WOMAN, HEARTH, SON, SKY, STEPPE (PLAIN), which all indicate the nomadic culture of Mongolian tribes. The reverse translation of the line the trembling blade of grass contains the sky sounds like the sky is contained in the fluttering blade of grass. The SKY concept is a derivative of the integral model of the world formed by Buryats' ancestors, and narrow meaning of SKY "is implemented and perceived in the framework of this model through involvement of a broad associative context" (Zhanaev, 2014: 3). The eternal high sky, indeed, occupies the highest position in the worldview hierarchy in the traditional everyday mind of Buryat people (the author is a traditional rep- tions of these concepts with the relevant target language dictionaries, thereby forming a certain stereotypical representation of the differences in the worldview of the bearers of both cultures.

This work procedure to pursue recognition of the inner world borne by representatives of different communities is connected with the fact that the psychophysiological nature of the images and ideas behind the word always remains opaque for the translator. Nevertheless, a thoughtful translator must be able to predict the content of everyday mind: starting from the stereotypical conceptual content the translator makes it relative both for the author and the recipient, first asking the question "What would I mean, what would I imagine if I were the addressee?", and then "How would I understand the translated thought of the sender, if I were the addressee?". 


\section{Conclusion}

1. The database, which is a frequency hierarchy of reproduction and perception of words, is an important resource for its further application in various research aspects. The significance of the resource is determined by our belief that multiple occurrence of certain words in a national language points to culturally significant clots of the meta-text in general, and of a specific text, in particular.

2. The associative meaning of the word-stimulus, which is the key to understanding the conceptual content of the everyday mind in bearers of the languages-cultures that come into contact through translation, has little in common with its dictionary meaning. Lexicographic interpretation is determined on the basis of the subject's scientific mind and is a foreknowledge in speech, while in thinking we depart from the conceptual content of everyday mind. This axiom is confirmed by the dif- ferences between the associative experiments data, which are shown in our paper, and explanatory monolingual dictionaries representing sets of static meanings of corresponding conceptual words.

3. We believe it wrong to assume that the unique conceptual content of the source culture bearer's everyday mind should be interpreted through the cognitive apparatus of the translator's language, as this would naturally lead to a distorted understanding and inadequate translation of texts with a convex conceptual content. If it is not possible to carry out experiments to identify the relevant (at the time of the source text production) associative content of the key concepts, the translator should refer to the data provided by associative dictionaries. A good translator, in our view, sets the task to acquire valid data indicating the conceptual worldview of the culture bearer, whose language is the source language of translation.

\section{References}

Bichakjian, B.H. (1999). Language Evolution and the Complexity Criterion. In: Psycoloquy. $10,33$.

Dashinimaeva, P.P. (2017). Teoriya perevoda. Psikholinguisticheskii podkhod [Translation theory. Psycholinguistic approach]. Ulan-Ude, Izdatel'stvo Buryatskogo gosuniversiteta, 360 p.

Dashinimaeva, P.P. (2017). Language Translatability and Culture Intranslatability Grounded by Psychoneurolinguistic Episteme. In: Yazykovye problemy perekhoda cherez kul'turu [Language problems of transition through culture]. Ulan-Ude, 4-8.

Dyrkheeva, G.A. (2017). Zhivaya rech' v Buryatii: k probleme izucheniya (sociolingvisticheskij obzor) [Colloqial Speech in Buryatia: on the stady of the problem (a sociolingusitic approach)]. In: Vestnik Tomskogo gosudarstvennogo universiteta. Filologiya [Tomsk State University Journal of Philology], 45, 77-88. DOI: $10.17223 / 19986645 / 45 / 5$

Lyashevskaya, O.N., Sharov S.A. (2017). Chastotnyj slovar' sovremennogo russkogo yazyka (na materialakh Natsional'nogo korpusa russkogo yazyka) [The New frequency dictionary of Russian vocabulary (on materials of the Russian National Corpus)]. Available at: http://dict.ruslang.ru/freq.php (accessed 2 March 2017).

Toury, G. (2004). Probabilistic explanations in translation studies: Welcome as they are, would they qualify as universals? In: Translation Universals. Do they exist? Amsterdam-Philadelphia, John Benjamins, 15-32.

Zhalsanova, Zh. (2017). Obraz “darhana/kuzneca” v buryatskoj kul'ture (psiholingvisticheskoe znachenie) [The Concept "Darchan/Smith" in the Buryat Culture (the psycholinguistic meaning)]. In: Vestnik Tomskogo gosudarstvennogo universiteta. Filologiya [Tomsk State University Journal of Philology], 45, 89-99. DOI: 10.17223/19986645/45/6

Zhanaev, A.T. (2014). (Ne)perevodimost' kontsepta v kul'turno-tsivilizatsionnom aspekte (na materiale buryatskikh kontseptual'nykh orientirov) [(In)translability of a concept in cultural and civilization aspect (on material of the Buryat conceptual reference points)]. Abstract of Philology Cand. Diss. Ulan-Ude. 


\title{
Концептуальное содержание обыденного сознания \\ би- и полилингва в ракурсе перевода
}

\section{П.П. Дашинимаева, Л.М. Орбодоева,}

\section{В.Б. Самбуева}

Бурятский государственньй университет

Российская Федерачия, Улан-Удэ

\begin{abstract}
Аннотация. Работа посвящена описанию механизма определения базового концептуального содержания обыденного сознания носителей разных культур и подтверждению идеи его нетождества, что ведет к соответствующему порядку аппликации данных в сфере межкультурной коммуникации. Для решения задачи авторы прибегают к многоступенчатой методике, совмещающей определение списка наиболее активной лексики, ассоциативный эксперимент, метод определения концепта на основе результатов эксперимента, определение аппликативности данных в переводческом посредничестве. 80 бурятскоязычных и русскоязычных студентов выступили в пилотном проекте респондентами, которые могут быть приняты в качестве представителей исходной и целевой культур (наличие коих обеспечивает основное условие процесса перевода). Актуальность темы обусловлена слабой разработанностью методологии экспликации концептов и соответствующего встраивания результатов в моделирование переводческого процесса.
\end{abstract}

Ключевые слова: обыденное сознание, перевод, эксперимент, ассоциат, образ, концепт, картина мира.

Исследование поддержано грантом Бурятского государственного университета, № 44-ОД от 09.02.2017.

Научная специальность: 10.02.19 - теория языка. 